Icaza, R. and R. Vazquez (forthcoming 2013), 'Social Struggles as Epistemic Struggles', Development and Change. Forum Special Issue on New Activism, Old Politics

\title{
Social Struggles as Epistemic Struggles
}

Rosalba Icaza and Rolando Vázquez

Version 18 Feb 2013

What does it mean to think of social struggles as epistemic struggles? What happens if we see social struggles as questioning our worldviews? This paper seeks to advance answers to these questions as an alternative route of engagement in the Activism 2010+ debate. In our view, to think social struggles as epistemic struggles is an invitation not so much to study them as objects, but rather to recognize the questions that they pose to our forms of understanding. With this, we aim to instigate an engagement with social struggles that includes not only their relation to economic and political forms of domination (e.g. neoliberal globalization), but also their capacity to generate knowledges and reveal the limits of our academic frameworks.

Our entry points in the Activism 2010+ debate are the questions 'why now' and 'what makes it distinctive'. These questions point towards establishing a temporal demarcation. We can recognize the importance of this debate in order to see, for example the role that new technologies are playing in the articulation of contemporary activisms. Moreover, the Activisms $2010+$ debate is from our perspective, a contribution to the understanding of 'different waves' of political activism traditionally associated in the literature on social movements to claims for political rights (XVII-XIX centuries), socio-economic rights (1950-1980s) and rights of recognition (1980s-to date). Although, following Zibechi (2005), we see in Latin America a movement that predates 2010 and that shows the emergence of activisms that are not anymore focused on claiming for rights in relation to the state, but that are fighting for 'dignity in autonomy'. These activisms have one of its most visible examples in the Zapatistas. They are activisms that fight to enact dignified life-worlds in autonomy from the major institutional framework of modernity: the state and the market. They are producing and theorizing other forms of the political, other economies, other knowledges. 
We do recognize the importance of identifying the waves in activism. However, we want to displace the focus from the concerns to define a before and an after, and that of determining what is novel or distinctive in contemporary waves of activism. In our view, the debate about marking a before and after 2010 in social struggles and the concurrent temporal classification, carries the risk of overlooking the synchronic existence of diverse forms of and claims in social struggles.

For us the question of time is also central, but we suggest an alternative approach to it. We deploy the question of time, in order to show that the temporality of social struggles is a temporality that cannot be squarely fit within a chronological order. We suggest that social struggles (like those of Chiapas and Seattle) are examples of events that break with the chronology of modernity and that in doing so they exceed our chronological frameworks of understanding.

Furthermore, temporality is central to our contribution but to show how social struggles can bring to question the ways in which these have been represented in the academia. To do this, the text inscribes itself in the literature on cognitive justice (RETOS 2010, Escobar 2007, Santos 2006), mobilizes the critique of modern time (Vázquez 2009), Arendt's notion of political event (Arendt 1989) and decolonial thought (Mignolo 2000).

Our argument is that the temporality of social struggle, their eventfulness, challenges the chronological narratives through which, more often than not, they are represented. For example, social struggles are often 'understood' as if they were the logical and almost necessary outcome of the structures of domination. On the other hand, we want to show that besides challenging the chronologies of the systems of domination social struggles also bring to question the epistemic structures that tend to normalize the order of oppression.

Approaching social struggles as epistemic struggles entails a move towards making visible the plurality of alternatives through which social life is being organized and experienced: "worlds otherwise" (Escobar 2007). Epistemic struggles aim at breaking 
down the hierarchies and exclusions related to the dominant representations of the real. These struggles come together with the collective realization of the historical imposition of values, knowledges and worldviews (Icaza 2012).

Academic analyses dealing with social struggle tend to be deeply rooted in particular approaches within social movements' theory: resource mobilization, political opportunities, framing, new social movements' theory, 'culturalist' perspective, and so on (Flores 2010). Recently, analyses inspired by social movements that make use of critical anthropology and ethnographic approaches, feminist epistemologies and decolonial thinking are considering the epistemic challenge that social movements entail (CasasCortes et. al. 2008, Conway 2006 and 2004, Flores 2007, Hale 2006, Leyva Solano et. al. 2011, Leyva Solando and Speed 2008). Furthermore, there is a growing literature that has been recognizing social movements as producers of knowledge (Casas Cortes et. al. 2008, Escobar 2010, Zibechi 2005). Central to these analyses are the questions how do we know what we know about experiences of social struggle, with which purposes and why?

Inspired by this literature and Arturo Escobar's invitation to (re)think theory through the political praxis of subaltern groups, our point of departure has been the analyses in the fields of International Relations (IR), International Political Economy (IPE) and Global Sociology (GS) dealing with two emblematic instances of social struggle of the late $20^{\text {th }}$ Century, namely the $1^{\text {st }}$ January 1994 indigenous Zapatista rebellion in the Southern state of Chiapas in Mexico and the $30^{\text {th }}$ November 1999 anti-corporate globalization 'Battle of Seattle' against the WTO Ministerial Summit (Escobar 2004).

To be sure, the uprising of Chiapas and the Battle of Seattle are not the only events of social struggle that could be included here. However our choice is not entirely arbitrary. On the one hand, the movements to which these events "belong" - the Zapatistas Communities in Resistance and their non-indigenous supporters and the so-called Global and Solidarity Justice Movement (GSJM) also referred as anti-corporate globalization or alter-mundialization movement- have been a constant reference in conversations and 
numerous encounters ${ }^{1}$ and workshops in which we have participated with activists, indigenous leaders, feminists and committed academics in the Americas, and more recently with participants of the Occupy and \#yo-soy-132 movements. ${ }^{2}$

On the other hand, these experiences of social struggle are cited over and over again in IPE/IR and GS literature as precedents to the GSJM and as inspiring decision making methodologies of Occupy Wall Street (OWS), Indignados and students mobilizations in Chile and Mexico (e.g. Drainville 2012, Gibson Graham 2006, Juris 2012, Sen and Waterman 2009, etc.). Furthermore, in this same literature they have been widely depicted as opposing the dominant logic of global capitalism (e.g. Morton 2002 and 2000, Olesen 2005, Holloway 2002), as subverting global orders and global forms of governmentality $^{3}$ and the way these have been explained (e.g. Coleman and Tucker 2011, Drainville 2012, Gill 2000, Lipschutz 2004). Meanwhile, a few of these studies have managed to explore the international resonance of these experiences of social struggle, for instance, in the case of Zapatismo it has been carefully traced how it has inspired "Northern" activists and their anti-capitalist and anti-power struggles (e.g. Khasnabish 2008).

This paper aims to contribute to these debates building on decolonial thought that has considered the Zapatista rebellion as a theoretical revolution (Mignolo 1997) and by thinking in which ways these social struggles, as 'epistemic struggles', call into question key concepts that are, again and again, reproduced and upheld by the academic frameworks of understanding.

\footnotetext{
1 Our thought is informed by over a decade of work with anti-corporate globalization collectives in the Americas and fruitful exchanges of ideas and encounters with participants and representatives of working class, women and indigenous movements.

2 The \#yo-soy-132 (\#I-am-132) movement also dubbed the 'Mexican Spring' emerged in the May of 2011 as a student led movement in Mexico concerned about media's allegedly biased coverage of the of the Presidential Campaigns. See http://www.yosoy132media.org/

${ }^{3}$ Recent work in IR/IPE has coined the term "global governmentality" extending the work of Foucault to theorize about organized practices through which subjects are governed at global, international, regional and supraterritorial dimensions (see: Larner and Walters 2004a and 2004b).
} 
In particular, we will try to show how social struggles signal a different understanding of "the political", and its temporality. In our view, the eventfulness of social struggle cannot be fully grasped just as a reaction to domination, or just as the necessary or logical outcome of the processes that precede them. Rather the eventfulness of social struggle characterizes the creative power that delinks its logic from that of the systems of oppression.

We contend that contrary to current analyses of social unrest in Egypt, Tunisia, Spain, the USA that interpret them as oppositional forces to the system(s) of domination, the struggles of Chiapas and Seattle (or the demonstrations in Tahir square, Plaza del Sol, Wall Street, Mexico City, Santiago and so on) bear political beginnings that cannot be fully determined by their opposition to the systems of domination and the order that they confront (e.g. Gills and Gray 2012, Rocamora 2012, Wallerstein 2011).

The eventful character of these social struggles illuminates the margins and the outside of the systems of domination. As political events, they break with the chronology of the processes of domination and bring to light the exteriority of modernity. They are not fully defined by their opposition to, rather we suggest reading them from the perspective of the alternatives that they bring to light. Accordingly, they are not only understood as being determined by their being against, by their resistance to modernity. They bring to visibility forms of understanding that do not belong to the genealogy of the modern forms of representation (Chiapas) or that disobey the dominant common sense ("There is no Alternative - TINA") (Seattle).

In order to develop these ideas, we start with a brief survey in international relations, international political economy and global sociology analyses on social struggles on the specific events of Chiapas and Seattle. In particular, we point to a key epistemic limitation that these literatures hold, namely that they reduce the understanding of social struggle to "the context" in which they emerge, thus cancelling the possibility of understanding events like Chiapas or Seattle as breaks with the continuity of the systems of oppression. 
We move on to put Hannah Arendt's notions of the political in dialogue with insights from decolonial thinking such as the notion of epistemic struggle. We find both in Arendt and decolonial thought opportunities to bridge the gap between academic narratives on social struggle and the very epistemic questions that these struggles present. It is important to note that to relate Arendt to the 'decolonial option', means to connect traditions of critique that belong to different genealogies (western critical thought and Latin American decolonial thought) which correspond to different conceptions of modernity and social justice. To bringing together different traditions of critique is for us a key analytical step. It is a way to move beyond universalism into forms of argumentation that are built on the possibility of a dialogue among a plurality of epistemic locations (Santos 2006, Mignolo 1997 and 2000, Waller and Marcos 2005).

Furthermore, this dialogue as an epistemic option allows us (as Mexican academics in European higher education) to highlight how academic frameworks are rooted in the modern/colonial order. Particularly when these frameworks uphold a view of academics as that of objective and detached observer of social struggles in the Global South. ${ }^{4}$ The academia is a key player in the geopolitics of knowledge, one that determines the 'prominence' of some activisms and not others, one that classifies struggles in temporal hierarchies and so on. Our position in the academia is inevitably marked by our being inbetween locations and it informs our interest to promote critical and intercultural exchanges in the generation of knowledge. ${ }^{5}$

We then ask what is made visible when we understand Chiapas rebellion and the Battle of Seattle also as epistemic struggles. We show how these events gave birth to previously unexpected conditions of visibility and recognition. They enacted a public realm in which the excluded and oppressed could speak and be heard, could act and be seen. These

\footnotetext{
${ }^{4}$ Our analysis is inspired by the positioned epistemologies ideas of US feminist anthropologist Dona Haraway, Argentinean feminist philosopher Maria Lugones and Mexican feminists Rosalva Aida Hernandez Castillo and Sylvia Marcos.

${ }^{5}$ There are some examples of an ongoing critical dialogue within IR/IPE/Global Sociology that include the research project on Modernity/Coloniality/De-Coloniality, the network Other Knowledges and the Programa de Democracia y Transformacion Global (PDTG), the Canadian-based project on Globalization and Autonomy, the UK-based project on Building Global Democracy, etc.
} 
political enactments shred the normalcy and continuity that enwraps the processes of domination.

\section{When social struggles become context}

It is common place that the literature dealing with the emergence of localized resistance with international and global repercussions explains this as a reaction or, at best, a dialectical response to neo-liberal globalization and its depoliticizing trends at the global, regional and local level (e.g. Gill 2003; Gills 2000; Wallerstein 2011). At the same time, accounts of the 1994 Zapatistas' uprising in Chiapas, Mexico and the Battle of Seattle during the WTO Ministerial Meeting of 1999 speak of the need to understand their implications well beyond national borders, and for other and subsequent citizen's mobilizations around the world (e.g. Bello 2000, Burbach 1994, Gill 2000). For example, in the IR/IPE and GS literature on social movements and social resistance inspired by Antonio Gramsci and Karl Polanyi's contemporary readings, the emergence of local and transnational forms of resistance to neo-liberal globalization is mainly explained as counter-hegemonic forces (e.g. Gill 2002 and 2003, Morton 2002, Gills 2003). In the conjuncture of neoliberal hegemony in the global economy, we are told, 'the sustained pressures for self-protection' (Gill 1997:217) from forces within civil society have sought to be organized in order to protect themselves from 'the atomising consequences of the market' (Hettne 1997:223). In these accounts, social resistance becomes the logical and often dialectical consequence of historical processes and its contexts (Icaza 2010).

For example, the emergence of the Ejercito Zapatista de Liberacion Nacional (EZLN), the armed movement of the "Zapatistas", indigenous communities of Tzotzil, Tzetzal, Chol, Tojolabal and Mame descent in Chiapas, is explained as a response to the restructuring of the capitalist system on a global scale, and part of the counter-movement of society aiming at protecting itself from market expansion envisaged by Karl Polanyi (Gill 2002; Morton 2002). Whereas in the case of Seattle, commentators have sought to present a detailed account of the agents' interventions and structural conditions, that 'erupted in Seattle' to contest neo-liberal globalization and capitalism and the protests 
have been defined as the beginning of an emerging international civil society (e.g. Gill 2000). In the same way, there have been other important efforts to study Seattle and Chiapas as part of a chain of processes that gave shape to transnational political bodies such as the World Social Forum (e.g. Waterman 2004).

Interestingly, in theses works Chiapas and Seattle are represented as outcomes of particular structural processes and their contexts. They are not thought as events that are in excess of their context. As such, the understanding of the context where social struggle emerged, that is, the history and the conditions of 'neo-liberal globalization' that accompanies it, is conflated with the understanding of the politics of the emergence of social struggles. In other words, the above mentioned academic narratives aim to understand social struggles as logical outcomes of ongoing processes within 'neo-liberal globalization', e.g. as a reaction to, as a double movement, as subaltern everyday forms of resistance. We believe that these sorts of analyses are valuable in their own disciplinary context, however we also see in them a methodological and theoretical problem that has limited the ability to perceive the political epistemic challenge that social struggles pose to our frameworks of understanding. In other words they are limited to perceive social struggles as originating political spaces and as enacting epistemic struggles.

When one looks at the increasing commercialization and depoliticization of social life, and the underlying instrumental rationality geared towards profit, and accumulation, it appears as if the wheels of history were set in an inexorable path towards the suppression of social equality, justice and political freedom. With this panorama it is hard to see how one can explain the emergence of social struggle running in a radically different direction. Chronological explanations have the effect of making invisible the break that their emergence signifies and their autonomy from the mechanisms of oppression. In fact, how within a chronology of domination can we ever think that events, such as Chiapas and Seattle, can have happened? In our view, to say that Chiapas and Seattle are just renegade offspring of 'neo-liberal globalization' is to disregard the creative power that social struggles hold, for example to question the limits of capitalism (e.g. anti-corporate 
emphases) but also the violence of modern/colonial institutions, such as the nation-state (e.g. repressive policy and military forces). It is to downplay the power that the silenced voices have when, in an act of resistance, they come into visibility shredding the veil of normalcy. Their resistance opens the space of the public, where they can speak and act, be heard and be seen in plurality, in dignity among others.

The assumption of a chronological conception of history leads to explanations unable to fully grasp the political freedom that social struggles hold. 'The awareness that they are about to make the continuum of history explode is characteristic of the revolutionary classes at the moment of their action' (Benjamin1992: 253). These events break with the chronology and with the instrumental rationality of the structures of oppression, thus they cannot simply be appropriated through a historical perspective based on rational processes or teleologies. In other words, rebellions that stand up against depoliticization, economic exploitation, and cultural alienation cannot be adequately understood through the same rationality that underlies the processes that they are breaking with. They are, rather, an open question to this dominant way of thinking and ordering of the real. These events challenge the epistemic hegemony of modernity.

\section{When social struggle is power}

In the introductory section of the Global Resistance Reader, Louise Amoore argues for the importance of "questioning what we think we know about global resistance" and "what we do not see and why our prevailing knowledge may leave aspects of global resistance in deep shadow" (Amoore, 2005:1). Recent accounts in IR and IPE literature inspired by Foucault's understanding of power have shed light into social dissent as processes of ordering (Coleman and Tucker 2011). This is certainly interesting, nonetheless to privilege a view of the systems of ordering and control precludes the possibility of thinking from the outside of those systems. The decolonial perspective invites us to think from the outside of the epistemic territoriality and the chronology of modern order of things. It is from this perspective that we suggest to take seriously the 
challenges that the events of Chiapas and Seattle pose to the way in which academics approach social struggle.

Finally, Andre Drainville's recent attempt to display the 'deeper roots and broader history' of the anti-neoliberal globalization movement tracks down 'episodes of struggles' across the world and shows them as situated and concrete manifestations of world ordering (Drainville 2011). In his study, men and women appear mostly as being 'subjectified' by world ordering, but in some instances, they appear also as 'true subjects of their own global history'. Drainville claims that true subjectivity is partly due to their 'unalienating mode or relation to the world economy' translated as the absence 'of political mediations and representations'. This view that pays attention to subjectivity, to episodes of resistance and to the lack of institutional mediations to analyze them, is indeed much closer to our view of social struggle, as it signals the limits of the world ordering mechanisms. However, we place here greater emphasis on the eventfulness of the episodes of social struggles that is, on their temporality and on their 'epistemic' dimension by listening to some of the questions that they pose.

\section{The Normalization of Chiapas and Seattle}

[E]ste viento de abajo, el de la rebeldía, el de la dignidad, no es sólo respuesta a la imposición del viento de arriba, no es sólo una brava contestación, lleva en sí una respuesta nueva... ${ }^{6}$ (EZLN: 1994:63 quoted by Ceceña 2001:139; EZLN 1994a).

There are some examples that show how social struggles and rebellions are represented as a set of processes, like Burbach's characterization of the Zapatista uprising as "the first postmodern rebellion" (Burbach 1994). The problem with this sort of analysis that reduces social struggle into a set of processes is that it explains rebellion as the outcome of capitalism, industrialisation, a failed social revolution and incomplete democratization in Mexico. 'The rebellion in Chiapas is the product of a quarter-century of capitalist modernization and resistance by peasant and Indian organizations' (Burbach 1994:123). We can hardly deny that such a statement is heavily laden with objective truth. However,

${ }^{6}$ 'This wind from bellow, from rebellion, from dignity, is not only an answer to the upper wind imposition, it is not simply a brave contestation, it bears within itself a novel answer' (our own translation). 
from our view, the limitation of this perspective is that the Zapatista rebellion seems to lose all its eventfulness in favour of becoming the logical consequence, the necessary result of a chronology of exploitation. The rebellion is thus deprived of an important part of its content, of its questioning, of its creative force.

Likewise, the literature about the Battle of Seattle represents it as an expression of a broad and diverse opposition to neoliberal global economic policies. For Smith, Seattle was "not the first, nor likely the last, in the contest to shape global economic, political, and societal integration. It is part of an interactive process of contention between elite and popular challengers that will have implications for the course of future conflicts and institutional changes" (Smith, 2002: 221).

In other cases, in an effort to contest corporate media's characterization of Seattle protesters as "anarchic irrationals", the Battle of Seattle is portrayed as a very well planned and meticulously organized event in which protesters were trained in pacifist tactics (Smith 2002; Thomas 2000). This was certainly true as one of the many participants to this event testified: "Before going to Seattle, we were trained in counter repression tactics, on how to protect ourselves, if the police bit us, we were told to protect our heads and never gave our name to them" (Interview A).

What we see happening in the literature mentioned above comes close to what Holloway notices in the political field: 'once the logic of power is adopted, the struggle against power is already lost' (Holloway, 2002). Basically the same logic of power, its epistemic framework is employed to see, describe and assess social struggles. By doing this, the literature hides the uniqueness of the event under the likeness of the processes of domination that precede it. It silences what we see as their radical questioning.

Let us be clear, with these reflections we are not trying to deny the work done in the organization of Seattle that many social scientist have documented (Smith 2002; Thomas 2000, Maeckelbergh 2009, Juris 2008). However, the analyses that tend to focus on evaluating the material, institutional or otherwise discursive 'impact' of it overlooks what 
we see as serious challenges to the ways we know what we know about social struggle. For example, some have evaluated whether Seattle protests really helped or not to close WTO negotiations and to change neoliberal discourses (Silver and Arrighi 2001). In other cases, commentators have sought to assess Seattle as a passive revolution or a transformative process. What interests us here is not to reject these contributions stemming from different analytical traditions, but rather to notice that in treating social struggles and their events as processes with incomes and outcomes other important aspects of their questioning are kept out of sight.

While recognizing the importance of social struggle literature, this rather schematic summary aims to show the importance of taking seriously the question of social struggles as epistemic struggles. It is worth noting that, only a handful of authors have been working to show the relevance social resistances for the study of IR, IPE and global sociology, they themselves provide a sort of resistance to the mainstream topics in their disciplines (e.g. Amoore 2005, Drainville 2011, Gill 2003). The work they have done has set the field with which our reflections are concerned. We seek to contribute to these debate by showing social struggles as on the one hand breaking the continuity of the processes of global capitalism and global governmentality, and on the other, opening public realms where politics is not an institutional procedure but the experience of acting and speaking while being heard and seen. By following Hannah Arendt, we will argue that the political dimension of events of social struggle have to be differentiated from the cause-consequence chains of modernity's processes of domination. Their movement cannot be reduced or normalized into the rationality of the political and economic processes characteristic of neoliberal globalization.

\section{Re-thinking the political with Hannah Arendt}

When social struggles are incorporated into historical chronologies, they are deprived of their eventfulness. We are usually assured that these are normal historical processes. 'Just as the current system of international trade dates back hundreds of years, so does the resistance to exploitative forms of global integration' (Broad and Heckscher 2003: 715). 
In which ways do social struggles when understood as political events differentiate from the politics of global capitalism's and in general of neoliberal governmentality? We will seek to address this question by deploying Hannah Arendt's political thought. Her conception of the event and the political can help us differentiate social struggles from the chronologies of domination. Arendt's vocabulary gives us a way to distinguish the political from the instrumental, chronological processes of society. It helps us to address the difficulty of conceiving the eventful character of social struggles at the epistemic level.

Hannah Arendt is a political thinker of the European tradition. She was committed to understanding the atrocities that her generation suffered under totalitarian regimes ${ }^{7}$. In contrast with most political theory, Arendt $^{8}$ provides a conceptualization of the political as a coming together where there is always the possibility of the unexpected to appear? From Arendt's perspective, the political is grounded in the coming together of people to constitute a public space, in contrast with notions of the political as mediated by institutions. When looking at social struggle we see precisely this coming together of people to speak and act in the public space, it is the essence of the political for Arendt: 'The space of appearance comes into being whenever men are together in the manner of speech and action, and therefore predates and precedes all formal constitution of the public realm and the various forms of government' (Arendt, 1989: 199).

Furthermore, when the unexpected nature of the event is put into motion, rebellions and uprisings can then appear not as the logical consequence of, but rather, as radical breaks with the seemingly irresistible processes of economic and political domination. In the

\footnotetext{
${ }^{7}$ For other efforts to bring the thought of Hannah Arendt to the understanding of globalization and international relation see Anthony F. Lang, Jr and John Williams (eds) 2005 Hannah Arendt and International Relations: Readings Across the Lines, New York: Palgrave.

${ }^{8}$ Certainly, Arendt's political ideas were often used in a normative way, against the backdrop of the modern state and rarely made reference to something like cross border or global resistance and 'global social relations', however we believe that her political concepts can be of great help to illuminate some crucial aspects of social resistances.

${ }^{9}$ For a more detailed study of Arendt's theoretical notion of the event see Vázquez Rolando 2006,Tbinking the Event with Hannah Arendt, European Journal of Social Theory 9(1): 43-57.
} 
following quote we can see Arendt's view of the political as a sphere that is not ruled by 'linear', chronological processes and where the unpredictable happens:

[I]t is not in the least superstitious, it is even a counsel of realism, to look for the unforeseeable and unpredictable, to be prepared for and to expect "miracles" in the political realm. And the more heavily the scales are weighted in favor of disaster, the more miraculous will the deed done in freedom appear; for it is disaster, not salvation, which always happens automatically and therefore always must appear to be irresistible (Arendt, 1993:170).

In other words, the event is not the result of the automatic processes and the rationality that characterize global capitalism but it is a radical break, a departure from such processes. For Arendt, the event cannot simply be explained away through analytical description. 'The very impact of an event is never wholly explicable; its factuality transcends in principle all anticipation' (Arendt 1993:169-170). The unexpected nature of the political event makes it a radical question to the given order of things. Thus, the uprisings of Chiapas and Seattle can be seen more as a question than as the logical outcome of a given set of pre-established processes, namely the processes of domination and exclusion of global capitalism or the violent imposition of hegemonic rationalities. To render the events as 'necessary outcomes', as the logical consequence of the processes of global capitalism or global governmentality is to silence their questioning. Let us say that this silencing reveals the epistemic power exercised by academic writing. We must be aware that academic writing can function to reinforce the epistemic territoriality of modernity and neutralize the questioning that comes from the outside (Vázquez 2011).

When seeing rebellions as political events they appear as openings, as spaces of visibility in which people come together to speak and act. In Arendt, the political event is also making visible the possibility of beginning something new. 'It is in the nature of beginning that something new is started which cannot be expected from whatever may have happened before. This character of startling unexpectedness is inherent in all beginnings and in all origins' (Arendt, 1989:177-178). The notion of beginning shows that although the event is radically unexpected, it is not fruitless or ephemeral. The 
political event can be seen as a beginning, that is as enacting the world as a space of interaction, of dialogue, of a coming together.

For Arendt the 'world' is not primarily a geographical space, but a social realm and the central concern of politics. '[T]he world and the people who inhabit it are not the same. The world lies between people, and this in-between-much more than (as is often thought) men or even man (sic) - is today the object of the greatest concern and the most obvious upheaval in almost all the countries of the globe' (Arendt, 1970:4). The world is social and political, not a 'physical space', its existence is assured only when people come together. The temporal qualities of political resistance have been underestimated in favor of spatial categories such as for instance the de-territorializing actions of civil society (Scholte 1999). By pinning down resistance to the vocabulary of space, these literatures reproduce at the epistemic level the modern chronology that the rebellions are questioning and with it, many of the dominant structures of knowledge.

From an Arendtian perspective we can differentiate the world from the geographical space in which the processes of modern rationality, global capitalism exercise their power. The 'world' for Arendt is a common realm, a reality that is shared, a reality that can only appear among subjects, in plurality. What is of the world is public and is visible. In contrast, the IPE, IR and GS literature inspired by neo-Gramscian and neo-Marxist ideas by passes the importance of the coming into visibility of the struggles for justice that most often remain represented within chronological frameworks of explanation ${ }^{10}$. For example, the roots of the Zapatista rebellion have been analysed by looking into "changing forms and relations of production in Chiapas during the 1970s which led to a growth of radical peasant organisations that would influence the formation of the EZLN" (Morton 2000). Meanwhile, accounts explaining the Battle of Seattle emphasize the fundamentally impoverishing nature of the neo-liberal project.

Arendt's conception of political freedom can only be understood in relation to the idea of the 'world' as an in-between, as a realm of togetherness: 'Freedom needed, in addition to

${ }^{10}$ On oblivion and the politics of time see Vázquez 2009 (op.cit.) 
mere liberation, the company of other men [sic] who were in the same state, and it needed a common public space to meet them - a politically organized world, in other words, into which each of the free men could insert himself by word and deed' (Arendt, 1993:148). However, she warns us that 'such a space of appearance is not to be taken for granted wherever men live together in a community' (Arendt, 1993:154). The coming to visibility of rebellion is the emergence of a 'public space'. The 'world' in itself is a political achievement; it is the outcome of the action of beginning, it is an enactment.

In order to distinguish our understanding of social struggle from the chronology of the processes of neo-liberal globalization and global governmentality we need to acknowledge the unexpected events that break with the continuity of the processes of domination. We shall then address events in social struggles such as the ones in Chiapas and Seattle as instances of this unforeseeable and unpredictable character of the politics of resistance. These particular events show the moment in which the continuities of the historical processes of global capitalism, of modernity are suspended; for example, by counterposing the battle of Seattle to the Multilateral Agreement on Investments (MAI) Free-Zone or with the public appearance of the EZLN on the same day that the North American Free Trade Agreement was coming into effect. It is as if by stopping the relentless progression of privatization, trade liberalization, consumption and individuation, they opened another temporality. These struggles assert themselves as political fights for visibility, for enacting the light of the public.

They reveal the hegemony of global capitalism as a machinery of suppression, of invisibility, of destruction of the political. They are counter-hegemonic in the Gramscian sense but they are not reducible to the negation of hegemony. They are enacting a power that brings to visibility words and deeds from the regions of society that have been marginalized, disdained or made absent. Arendt's notion of power can help us see this creative element of resistance that is nor reducible to its negation of oppression:

'Power is actualized only where word and deed have not parted company, where words are not empty and deeds not brutal, where words are not used to veil 
intentions but to disclose realities, and deeds are not used to violate and destroy but to establish relations and create new realities' (Arendt, 1989:200).

The autonomous forms of government that the Zapatistas have exercised since the rebellion are a living proof of a politics where words and deeds come together. The Zapatista notion of politics comes close to these arguments from Hannah Arendt, but its inspiration does not come from the western genealogy of thought, their politics is largely based in the mayan indigeneous philosophies in which the idea of togetherness plays a central role (Lekersdorf 2002). In a way, Arendt is helpful here to make a bridge from the internal critique of modernity and western academic knowledge, in which this article is inscribed, towards recognizing and valuing other conceptions of the political (Dussel, 2008; Villoro 2009).

Social struggles are the moments in which this sort of political power is actualized by the coming together of people, by the confluence of speaking and acting. Where speaking is challenging the silencing of oppression, this speaking is an act of political freedom, a conquest of dignity. And where action is not oriented to appropriate, but rather to open a public space of emancipated social realities. The modern power of appropriation and fragmentation is challenged by the acting together, the modern power of representation is challenged by the speaking together. In this way the political event posses a radical critique to the modern/colonial system of domination, to its mechanisms of appropriation and representation. In a similar vein Escobar (2004) develops an analysis on the emergence of self-organizing social movement networks. He claims that these operate under a 'new logic' and beyond 'modern categories' when they 'engage with the politics of difference and particularly through place-based yet transnationalised political strategies' (Escobar 2004).

\section{Contributions from the decolonial option}

Let us now show how our analysis on the eventfulness of the political connects with the decolonial school of thought. Decolonial thought is grounded in the understanding of the constitutive relation that exists between modernity and coloniality (Quijano 2000). 
Whereas modernity holds the monopoly of representation, coloniality signals what remains invisible or absent under the modern/colonial system. We would argue that what the rebellions are doing in their eventfulness is to challenge the monopoly of modernity over the representation and the appropriation of the real. They can be read as decolonial moves in that they bring to visibility the voices that have been silenced; they open a public space where actions of political freedom and dignity can happen. In doing this we see these rebellions as challenging the modern/colonial epistemic frameworks of understanding. They challenge the modern/colonial notions of chronology and the political that have long functioned to normalize the systems of oppression. In this vein, Walter Mignolo says: "The theoretical revolution of Zapatismo consists, precisely, in the transformative integration of subalternized gnosologies (like that in Andean language and knowledges) in doing of the social movement a theoretical intervention more than a socio-historical happening that could be reduced to be an "object" of study" (Mignolo 1997: 5) ${ }^{11}$. Meanwhile, the Battle of Seattle as a political beginning brought, from the political margins of the consumer society, labor unionists, pacifist, anarchists, feminists, environmentalists groups and collectives together to act and speak gainst the WTO and the replacement of the TINA metaphor in favor of "Other Worlds are possible" suspending in this way the normalcy of top-down opaque international political negotiations.

\section{Snapshots}

So many struggles,

so many ways of expressing our rejection to capitalism, so many ways of fighting for our dream of a different society are filtered out, simply remain unseen when the world is seen through the prism of the conquest of power.

We learn to suppress them, and thus to suppress ourselves.

John Holloway, Changing the World without Taking Power

\footnotetext{
11 our own translation
} 
What does it mean to think the event in relation to social struggle? This question leads to thinking activism beyond the confines of modern temporality, that is beyond the chronological ordering between past-present-future, or the classification of Post-2010 activisms. It also leads to a different way of understanding 'the political'. Let us step on Hannah Arendt's conception of a beginning, as it will allow us to refocus the particular relation that social struggles such as that of the events of Chiapas uprising and the Battle of Seattle hold with historical time.

'It is in the very nature of a beginning to carry with itself a measure of complete arbitrariness. Not only is it not bound into a reliable chain of cause and effect, a chain in which each effect immediately turns into the cause for future developments, the beginning has, as it were, nothing whatsoever to hold on to; it is as though it came out of nowhere in either time or space. For a moment, the moment of beginning, it is as though the beginner had abolished the sequence of temporality itself, or as though the actors were thrown out of the temporal order and its continuity' (Arendt 1990:206).

From Arendt's notion of beginning, we can venture an approach to social struggles, as those of Chiapas and Seattle, as contestations to global capitalism and global governmentality. But also as departures from the rational processes and the temporality that are in place in global capitalism and its dominant rationalities as we indicated in the examples provided above. These struggles constitute a beginning and as such they have shattered the continuity of the mechanism of domination. They have opened the way to a political visibility where the voices of the marginalized and oppressed can be heard. Indigenous people in the South of Mexico from tzotzil, tzetzal, chol and mame descent and community activists and environmentalists questioning the benefits of free-trade as beneficial for all. They bring to the light of the public what has been disdained, what has been denied recognition, what has been denied existence (Santos 2006). As if they were a spark of hope coming from the outside, from beyond the confines of modernity. This vision of a beginning is clearly conveyed in the accounts made by spectators, in them we see how much these struggles were unexpected and how they appeared as a question to the normalized order of things. 
"As protesters were beaten, gassed, clubbed, and pushed back, a new group would replace them. There were no charismatic leaders barking orders. There was no command chain. There was no one in charge.

Meanwhile, the WTO meeting couldn't start. Demonstrators were everywhere. Private security guards locked down the hotels. The downtown stores were shut. Hundreds of delegates were on the street trying to get into the Convention Center. No one could help them.

For WTO delegates accustomed to an ordered corporate or governmental world, it was a calamity". (Paul Hawken) ${ }^{12}$

"Before the rebellion in Chiapas, the key word in Mexico was "modernization," the illusion of the First World around the corner: "Happiness is here again for the first time". "Modernization" took the place of nationalism, the old-time "act" that united all sectors through festivity, mythology. And Chiapas, I think, was powerful in destroying, first, the mirage of "modernity" and, second, that kind of nationalist mythology. It led to the discovery of a Hollywood scenario, the result of government know-how. We had really lived in a world of make-believe. For the first time we asked: How was it possible that we could believe in a Noah's ark of the happy few, and that we could overlook the existence of ten million Indians?" (Carlos Monsivais) $^{13}$

The veil of normalcy that covers the modern/colonial world of inequality and social injustice was shredded by the Chiapas rebellion and the Battle of Seattle. The rejection of the way things are under global capitalism and the rhetoric of modernity (Mignolo 2000) was voiced and appeared in the light of the public, this rejection took a political dimension. According to Arendt 'it is this character of startling unexpectedness what characterizes all beginnings and all origins' (Arendt, 1989: 178). These events are not simply a reaction, but they are moments of emergence of a public realm that challenges the condition of oppression prevailing in global capitalism and more generally in the modern/colonial order.

Of course, we are not saying here that the Zapatista uprising in Chiapas is not related to the five hundred years of oppression and inequity against Indigenous groups since the Spanish colony (Burbach 1994; Harvey 1998), or that the battle of Seattle was not related

\footnotetext{
12 This extract is quoted from "WTO: Inside, Outside, All Around The World" available at: wnw.globalpolicy.org/globaliz/cvlsocty/wtopost.htm. The emphasis does not appear in the original text.

13 This extracts is quoted from David Thelen "Mexico's Cultural Landscapes: A Conversation with Carlos Monsivais", The Journal of American History, Vol. 86, No. 2: 613-614. The emphasis does not appears in the original text.
} 
to the two hundred years of industrial capitalist exploitation of people and nature. What we are saying is that these histories of oppression came unexpectedly into the light of the public. While doing this, we warn against the risk of normalizing these events, by turning them into logical outcomes of the processes of domination. In making public the historical demands of the oppressed, rebellions have reclaimed political dignity. The public emergence of the oppressed breaks the power of silencing, of absencing, of depoliticization and oblivion, in brief, the coloniality in which they have been traditionally immersed.

'Behind us we are you. Behind our mask is the face of every excluded woman... of all the death by oblivion. Of all simple and ordinary men and woman that don't count, that are not seen, that are not named, that have no tomorrow ${ }^{14}$ (Mayor Ana María EZLN 1996: 102-103 in Ceceña 2001: 134).

Chiapas and Seattle represent the coming to visibility and the mutual recognition that the fight for justice requires to become political in the way that Arendt understood politics. That is, the struggles against social injustice challenged the exclusion of the oppressed from the realm of visibility. The light of the public disrupted the oppression of disdain, the invisibility of depoliticisation. Hannah Arendt shows us that the possibility of speaking and being heard is a necessary condition for the attainment of political freedom.

[F]reedom, which only seldom-in times of crisis or revolution-becomes the direct aim of political action, is actually the reason that men live together in political organization at all. Without it, political life as such would be meaningless. The raison d'être of politics is freedom, and its field of experience is action. (Arendt 1993:146)

The recognition of the eventfulness of these rebellions is also to recognize their achievements. The event in shattering the normalization of the automatic processes of domination, opens a public realm, in which injustice and liberation come to visibility. What was outside of the scope of Arendt was to see that this coming into visibility of the political event, in cases like the Chiapas rebellion or the Battle of Seattle, is also a

\footnotetext{
14 "Detrás de nosotros estamos ustedes. Detrás de nuestro pasamontañas esta el rostro de todas las mujeres excluidas. . . . De todos los muertos de olvido. De todos los hombres y mujeres simples y ordinarios que no cuentan, que no son vistos, que no son nombrados, que no tienen mañana" (our own translation)
} 
decolonial move in that it enacts the voices, the claims, the histories that have been denied existence under the modern/colonial system of oppression. These are decolonial rebellions in the sense that they challenge the totality of modernity from its inside ${ }^{15}$ in the case of Seattle and from its outside in the case of Chiapas. These events pave the way towards a different exercise of politics both at the local and at the transborder level. Decolonial rebellions carry with them forms of understanding that disobey the epistemic frameworks, the dominant narratives of the modern/colonial order. 'By being happenings that produce thought, they are happenings that cannot be 'trapped' as objects of study and classified in the shelf of the already known' (Mignolo 1997:11). These rebellions introduce forms of thinking and vocabularies into the public sphere that, in the case of Chiapas, do not belong to the tradition of modernity or that, in the case of Seattle, challenge the hegemonic common sense. In this way, these struggles for social justice can also be read as struggles for epistemic justice. Seattle is a struggle that originates in the margins but within the western consumer society, in a sense it is internal to modernity. In contrast, the rebellion of Chiapas originates in the outside of modernity. It has its roots in 500 years of coloniality and enacts many principles of indigenous philosophies that do not belong to the Western tradition of thought. It is crucial to emphasize that the differences between Chiapas and Seattle are extensive. We are bringing them together in order to challenge the way in which social struggles have been represented in academic disciplines, such as IR, IPE and GS.

\section{Final Thoughts}

The approaches to 'politics' as the sum of the instrumental actions of individuals or institutions renders invisible the political lessons, the political alternatives presented by the events of social struggles. International Political Economy, International Relations and Global Sociology literature, by re-inscribing the events of struggles such as Chiapas and Seattle within a historical chronology, a sequence of processes, normalizes them. The events are deprived of their power to question our ways of understanding and making the political. 'Neoliberal globalization', the context, is often taken to be the primary source of

\footnotetext{
${ }^{15}$ To read more on the inside and the outside of modernity see Dussel 1995.
} 
explanation. More often than not, these events are described in what they negate and not in what they positively create. In other words, they are primarily represented as reactions to the structures of oppression, and only secondarily as leading to alternative political practices and experiences.

The problem is what remains unseen when the political event is measured against the backdrop of the processes of neoliberal globalization, or rather, when these processes are used as the main reference framework to evaluate political events. These approaches obviate the importance of the event in itself as a political enactment and have the effect of normalizing struggles within the hegemonic chronologies.

The approaches to 'politics' as conjunctions of instrumental actions render invisible the political delinking that the words and deeds of the rebellions are enacting. While acknowledging the scientific relevance of detecting, describing and measuring the impact of the networks and coalitions that preceded these events, we argue that it is necessary to allow for the possibility of approaching social struggle not as outcomes but as beginnings, not as modern reaction but as decolonial recreations. In our view these struggles are not primarily oppositions to the institutions of modernity but alternatives to the market and the state.

This is not to propose a 'novel' characterization or typology of activisms, but to point at what we were able to perceive by 'listening' to the political and epistemic praxis of social struggles. They appear then as opening public realms, where the excluded and oppressed, those who have been disdained come to visibility with their own voice and words. They signal a movement of liberation, of dignity in autonomy. They open a public space that was not there before. Their words and deeds are already an acting and thinking together delinking from the active processes of silencing, of absencing that come with modernity. To see the creative force of social struggles requires us to go beyond their representation solely as opposition to the established powers or as part and parcel of dominant orders (Lugones 2008). 
Arendt, saw in the political event an opening of the public realm that is necessary for the realization of political freedom. In understanding the eventful temporality of resistance, we can begin to make sense of the political freedom that it bears. Chiapas and Seattle brought to visibility, to the light of the public, the silenced voices while breaking with the continuity of the processes of oppression. They called to question the chronology of historical necessity that underlies the ideologies and epistemologies of modernity. Radical political freedom cannot be grasped from within the logic of causality and the very frameworks that underpin the structures of oppression. Radical political freedom questions instrumental reason and hence the scaffolding that holds together the narratives of global capitalism and more generally the mirage of modernity. Listening at social struggles as epistemic struggles requires opening to question our ways of thinking.

\section{Bibliography}

Amoore, L. (2005). "Introduction. Global resistance-global politics", in Louise Amoore, The Global Resistance Reader, Abingdon, Oxon, Routledge: 1-11.

Arendt, Hannah (1989). The Human Condition. Chicago and London, The University of Chicago Press.

Arendt, Hannah (1990). On Revolution. London, Penguin.

Arendt, Hannah (1993). What is Freedom? Between Past and Future, Eight Exercises in Political Thought. London, Penguin: 143-171.

Bello, W. (2000). 2000: the year of global protest against globalization Available at: www.nadir.org/nadir/initiativ/agp/free/bello/2000global_protest.htm.

Benjamin, W. (1992). 'Theses on the Philosophy of History' in Illuminations, London: Fontana Press.

Broad, R. and Z. Heckscher (2003). "Before Seattle: the Historical Roots of the Current Movement Against Corporate-led Globalization." Third World Quarterly 24(4): 713-28.

Burbach, R. (1994). "Roots of the Postmodern Rebellion in Chiapas." New Left Review, I, 205.

Ceceña, Ana Esther (2001) "Por la Humanidad y Contra el Neoliberalismo. Líneas Centrales del Discurso Zapatista", in Jose Seoane and Emilio Taddei (comp.) Resistencias Mundiales. De Seattle a Porto Alegre. Buenos Aires: CLACSO: 131140.

Casas-Cortés, M. I., Osterweil, M. \& Powell, D. (2008) Blurring Boundaries: Recognizing Knowledge-Practices in the Study of Social Movements. Anthropology Quarterly, 81, 17-58. 
Castro-Gomez, Santiago (2007) Michel foucault y la colonialidad del poder. Tabula Rasa. Bogotá - Colombia, No.6: 153-172.

Conway, Janet (2006) Praxis and Politics: Knowledge Production in Social Movements. London: Routledge

Conway, Janet (2004) Identity, Place, Knowledge: Social Movements Contesting Globalization. Toronto, Candada: Fernwood Publishing Co.

Drainville, André (2011) A History of World Order and Resistance: The making and unmaking of global subjects. Rethinking Globalizations, New-York and London: Routledge.

Dussel, Enrique (1995) The Invention of the Americas: Eclipse of "the Other"'and the Myth of Modernity, New York: Continuum.

Dussel, Enrique (2008) Twenty Theses on Politics. Durham and London: Duke University Press.

Escobar, A. (2004). "Beyond the Third World: imperial globality, global coloniality and anti-globalisation social movements." Third World Quarterly 25(1): 207-30.

Escobar, A. (2007) "World and Knowledge Otherwise". Cultural Studies 21 92-3): 179210.

Escobar, A. (2010) "Latin America at a Crossroads". Cultural Studies 24:1, 1-65.

EZLN (1994) Documentos y Comunicados. Mexico: ERA.

EZLN (1994a) "Chiapas: el Sureste en dos vientos, una tormenta y una profecía". Departamento de Prensa y Propaganda, EZLN Selva Lacandona. México, enero de 1994. Available at: http://www.ezln.org/documentos/1994/199208xx.es.htm

Florez Florez, Juliana (2010) Lecturas emergentes : Decolonialidad y subjetividad en las teorías de movimientos sociales. Bogota, Colombia: Pontificia Univ. Javeriana

Florez Florez, Juliana (2007) Lectura no eurocéntrica de los movimientos socialeslatinoamericanos. Las claves analíticas del proyectomodernidad/colonialidad. In Santiago Castro-Gomez and Ramon Grosfoguel (eds.) El Giro Decolonial. Reflexiones para una diversidad epistemica mas alla del capitalism global. Bogota, Colombia: Ponticifia Universidad Javeriana, pp. 243-266.

Gibson-Graham, J.K. (2006) A post-Capitalist Politics. Minnesota: Minnesota University Press.

Gill, S. (2000). "Toward a Postmodern Prince? The Battle in Seattle as a Moment in the New Politics of Globalisation." Millenium: Journal of International Studies 29(1): 131-140.

Gill, S. (2002). "Theorizing the interregnum. The double movement and global politics in the 1990s". in Louise Amoore, The Global Resistance Reader, Abingdon, Oxon, Routledge: 54-64.

Gill, S. (2003). Power and Resistance in the New World Order Basingstoke, Palgrave Macmillan.

Gills, B.K. and Gray, K. (2012) People Power in the Era of Global Crisis: rebellion, resistance, and liberation, Third World Quarterly, 33 (2), pp. 205-224.

Gills, B. K., Ed. (2000). Globalisation and the Politics of Resistance London, Palgrave. 
Hale, Charles R. (2006) Activist Research v. Cultural Critique: Indigenous Land Rights and the Contradictions of Politically Engaged Anthropology. Cultural Anthropology, Vol. 21, Issue 1, pp. 96-120

Halliday, F. (2000). " Getting Real About Seattle." Millenium: Journal of International Studies 29(1): 123-29.

Harvey, N. (1998). The Chiapas Rebellion: The Struggle for Land and Democracy. Duham, Duke University Press.

Hayduk, R. (2012) Global Justice and Occupy Wall Street: Movement Connections. Socialism and Democracy 26 (2) pp 43-50.

Holloway, J. (2002). Change the World Without Taking Power: The Meaning of Revolution Today, London: Pluto Press.

Icaza, Rosalba (2012) "Rethinking the "new" North America through Women's Citizenship Struggles in Mexico" in Ayres, Jeffrey and MacDonald, Laura eds, North America in Question: Regional Integration in an era of political economic turbulence, Toronto: University of Toronto Press, pp. 309-333

Icaza, Rosalba (2010) Global Europe, Guilty! Contesting EU Neo-liberal Governance to Latin America, in Third World Quarterly, 3 (12), 123-139.

Jaeger, HM (2007)'Global civil society and the political depoliticization of global governance', International Political Sociology, 1(3), 257-277.

Juris, Jeffrey S. (2012) Reflections on \#Occupy Everywhere: Social Media, Public Space, and Emerging Logics of Aggregation. American Ethnologist 39:259-279.

Juris, Jeffrey (2008) Networking Futures. The Movements Against Corporate Globalization, Durham: Duke University Press.

Kaldor, M. (2000). Civilising' Globalisation? The Implications of the 'Battle in Seattle'. Millenium: Journal of International Studies 29(1): 105-14.

Khasnabish, Alex (2008) Zapatismo Beyond Borders: New Imaginations of Political Possibility. Toronto: University of Toronto Press.

Lang, Anthony F. Jr and John Williams (eds) 2005 Hannah Arendt and International Relations: Readings Across the Lines, New York: Palgrave.

Larner, Wendy and William Walters (2004b) Globalization as Governmentality. Alternatives: Global, Local, Political, vol. 29, no. 5, Governing Society Today (Nov.-Dec), pp. 495-514.

Larner, Wendy and WilliamWalters, eds. (2004a) Global Governmentality: Governing International Spaces. London: Routledge.

Lenkersdorf, Carlos (2002) Filosofar en clave tojolabal. Mexico City: Miguel Angel Porrúa.

Leyva Solano, et. al. (2011) Conocimientos y Practicas Politicas: Reflexiones desde nuestras practicas de conocimiento situado. CIESAS, UNICACH, PDTGUNMSM: Chiapas, Ciudad de México, Ciudad de Guatemala y Lima.

Leyva Solano, Xochitl, and Shannon Speed (2008) Hacia la investigacion descolonizada: nuestra experiencia de colabor in Xochitl Leyva, et al. (coord). Gobernar en la diversidad: experiencias indigenas desde America Latina. Hacia la investigacion de colabor. Mexico: CIESAS-FLACSO, pp. 65-110.

Lipschutz, R. (2004) Global civil society and global govermentality: or, the search for politics and the state amidst the capillaries of social power, in M. Barnett and R. 
Duvall, Power in Global Governance. Cambridge and London, Cambridge University Press, 229-248.

Lugones, Maria (2003) Pilgrimages/Peregrinajes:Theorizing Coalition against Multiple Oppressions,Boulder,CO: Rowman and Littlefield.

Maeckelbergh, Marianne (2009) The Will of the Many: How the Alterglobalisation Movement is Changing the Face of Democracy. London: Pluto Press.

Mignolo, W. (1997). La revolución teórica del zapatismo: sus consecuencias históricas, éticas y políticas, Orbis Tertius II (5): 1-12.

Mignolo, W. (2000). Local Histories/Global Designs, Coloniality, Subaltern Knowledges, and Border Thinking. Princeton, New Jersey: Princeton University Press.

Morton, D. A. (2002). "La Resurrección del Maíz: Globalisation, Resistance and the Zapatistas." Millenium: Journal of International Studies 31(1): 27-54.

Morton, A. D. (2000). "Mexico, Neoliberal Restructuring and the EZLN: A NeoGramscian Analysis", in Barry K. Gills (ed.) Globalisation and the Politics of Resistance London, Palgrave: 255-272.

Movements (2003). Seattle, Florence, Porto Alegre: 1'autre mondialisation. Movements, 25, 5-91.

Olesen, Thomas (2005) International Zapatismo: The Construction of Solidarity in the Age of Globalization, London: Zed Books.

Quijano, A. (2000). Coloniality of Power, Eurocentrism, and Latin America. Nepantla: Views from South , 1 (3), 533-580.

RETOS, La red transnacional otros saberes, 2012, About the Transnational Network of Other Knowledges, www.encuentroredtoschiapas.jkopkutik.org, last accessed 0612-12.

Rashid, Asaf (2011). A Critical Discussing of the Occupy Movement. An Interview with Alex Khasnabish. Available at Halifax Media Co-op. http://halifax.mediacoop.ca/audio/re-occupy-movement-interview-alexkhasnabish/8539

Rocamora, J. (2012) People power is alive and well. Third World Quarterly 33 (2) pp. 201- 204.

Rupert, M. (2002). The new world order. Passive revolutions or transformative process" in Louise Amoore, The Global Resistance Reader, Abingdon, Oxon, Routledge:194-207.

Sader, E. (2001). "Antes e depois de Seattle." Revista del Observatorio Social de América Latina 3.

Santos, B. S. (2006). The Rise of the Global Left, The World Social Foruym and Beyond. London: Zed Books.

Scholte, J. A. ed. (2007) Building Global Democracy? Civil Society and Accountable Global Governance. Cambridge: Cambridge University Press.

Scholte, J. A. (2000). " Cautionary Reflections on Seattle." Millenium: Journal of International Studies 29(1): 115-21.

Scholte, J. A. (1999). Global civil society: Changing the world? CSGR Working Paper No. 31/99, Centre for the Study of Globalisation and Regionalisation, University of Warwick, UK. www.csgr.org

Sen, Jai and Peter Waterman, eds. (2009) World Social Forum. Challenging Empires. Second Edition, London: Black Rose Books. 
Silver, B. J. and G. Arrighi (2001). Workers North and South in Louise Amoore, ed. The Global Resistance Reader. Abingdon, Oxon, Routledge: 271-88.

Smith, Jackie, Rosalba Icaza, Rolando Vazquez, et. al. (2013, forthcoming) Global Democracy and the World Social Forum. Second Edition. Paradigm Publishers.

Smith, Jackie, Rosalba Icaza, Rolando Vazquez, et. al. (2007) Global Democracy and the World Social Forum. Paradigm Publishers.

Smith, J. (2002) "Globalizing Resistance: The Battle of Seattle and the Future of Social Movements", in Jackie Smith et.al. Globalization and Resistance. The Transnational Dimensions of Social Movements. Lanham, Maryland, Rowman and Littlefield Publishers: 207-29.

Teivainen, T. (2002). "The World Social Forum and global democratisation: learning from Porto Alegre." Third World Quarterly 23(4): 621 - 32.

Thomas, J. (2000). The Battle in Seattle: The Story Behind and Beyond the Wto Demonstrations Fulcrum Publishing.

Vazquez, R. (2006). "Thinking the Event with Hannah Arendt." European Journal of Social Theory 9(1): 43-57.

Vazquez, R. (2009). Modernity Coloniality and Visibility: The Politics of Time, Sociological Research Online, volume 14, issue 4. http://www.socresonline.org.uk/14/4/7.html

Vázquez, R (2011). Translation as Erasure, exploring modernity's epistemic violence, Journal of Historical Sociology, 24(1): 27-44.

Villoro, Luis (2009). Tres retos de la sociedad por venir: justicia, democracia, pluralidad. Mexico City: Siglo XXI Editores.

Wallerstein (2011) 'The fantastic success of Occupy Wall Street'. Commentary No. 315, http://www.iwallerstein.com/fantastic-success-occupy-wall-street/

Waller, Marguerite and Sylvia Marcos (2005) Dialogue and Difference. Feminisms Challenge Globalization. Basingstoke: England. Palgrave MacMillan

Walsh, Catherine (2007). "Shifting the Geopolitics of Critical Knowledge. Decolonial thought and cultural studies 'others' in the Andes". Cultural Studies, 21, issue 2 \&3: 224-239.

Waterman, P. (2004). "The World Social Forum and the Global Justice and Solidarity Movement: A Backgrounder" in J. Sen;, A. Anand; A. Escobar; and P. Waterman. The World Social Forum: Challenging Empires. New Delhi, Viveka Publications.

Zibechi, R. (2005). "Subterranean echos: Resistance and politics "desde el Sótano". Socialism and Democracy, 19:3, 13-39.

Interview A. 2008. Mexican Activist from the Mexican Network against Free Trade (RMALC). Guatemala Social Forum, October 10th, 2008. Interview conducted by Rosalba Icaza. 